\title{
Red deer vs. ibex hunting at a seasonal base camp in the Dolomites: Mondeval de Sora, site 1 , sector I
}

\author{
Ursula Thun Hohenstein*, Maria Chiara Turrini, Antonio Guerreschi, Federica Fontana \\ Department of Humanities, University of Ferrara, Corso Ercole I d'Este 3244121 Ferrara, Italy
}

\section{A R T I C L E I N F O}

\section{Article history:}

Available online $\mathrm{xxx}$

\section{Keywords:}

Dolomites-Alps

Sauveterrian

Red deer

Ibex

Animal resource exploitation

Taphonomy

\begin{abstract}
A B S T R A C T
Mondeval de Sora is situated in the heart of the Dolomites (south-eastern Alps, Italy) at an altitude of about $2150 \mathrm{~m}$ a.s.l.; this site represents a key deposit for the study of occupation and exploitation patterns of mountain areas in the southern slope of the Alps during the early Holocene. This paper contains the results of the study of the faunal assemblages coming from the Sauveterrian levels of sector I, located under the side of the erratic boulder facing south-east. The faunal assemblages of I sector come from two stratigraphic units (SSUU 8 and 31) and are characterised by a great variety of faunal resources: the most represented species are red deer and ibex, the hunting of which was favoured by the optimal location of the site, followed by a moderate quantity of chamois and roe deer. Wild boar is scarce and carnivores (bear, wolf and fox) are rare. The taphonomic analysis of the faunal macro-remains have demonstrated that the processing of animal carcasses, especially of red deer and ibex, were mostly carried out in the site.
\end{abstract}

๑ 2016 Elsevier Ltd and INQUA. All rights reserved.

\section{Introduction}

This paper discusses the results of the recent archaeozoological analyses carried out on the faunal assemblages from the Sauveterrian (Early Mesolithic) layers of the mountain camp-site of Mondeval de Sora, sector I (Belluno Dolomites, south-eastern Alps) and aims at highlighting the strategies of animal resource exploitation and contributing to the definition of settlement dynamics in the site.

In the south-eastern Alps several high altitude and valleybottom early Mesolithic sites have been discovered since the 1970s (Broglio, 1973, 1980, 1992). At the current state of research in most cases only valley-bottom deposits have yielded complex stratigraphical sequences and organic remains thanks to their location under rock-shelters (Boscato and Sala, 1980; Clark, 2000; Wierer and Boscato, 2006; Crezzini et al., 2014) while mountain sites are most frequently open-air and characterized only by the presence of lithic scatters, thus limiting the availability of elements useful to a more systematic assessment of their functional role (Fontana, 2011). Only a few exceptions can be quoted such as Grotta d'Ernesto cave site (Awsiuk et al., 1991), La Cogola rock-shelter (Dalmeri, 2004; Fiore and Tagliacozzo, 2004) and Plan de Frea,

\footnotetext{
* Corresponding author.

E-mail addresses: ursula.thun@unife.it (U. Thun Hohenstein), trm@unife.it (M.C. Turrini), gue@unife.it (A. Guerreschi), federica.fontana@unife.it (F. Fontana).
}

which is located under a large erratic boulder in the Dolomite area (Angelucci et al., 1998) as Mondeval de Sora. The first two sites are situated at around $1000 \mathrm{~m}$ a.s.l. in the Pre-Alpine area while Plan de Frea and Mondeval de Sora lie at around $2000 \mathrm{~m}$ a.s.l. in the inner Alps and are therefore strictly comparable one to another.

\section{The site}

The site of Mondeval de Sora (San Vito di Cadore, Belluno), which represents a key deposit for the study of mountain exploitation systems in the Southern Alps during the early Holocene, is located in the Belluno Dolomites at an altitude of approximately $2150 \mathrm{~m}$ above sea level. Two different sectors (sector I and sector III) have been explored, situated under the same large erratic boulder (Fig. 1; Alciati et al., 1992; Fontana and Vullo, 2000; Fontana and Guerreschi, 2003; Fontana et al., 2009b).

Sector I was excavated between 1986 and 1996. It was explored over a surface of about $60 \mathrm{~m}^{2}$ allowing the identification of a stratigraphic series with layers spanning from the ancient Mesolithic (Sauveterrian) to the modern age. It includes a recent Mesolithic (Castelnovian) burial accompanied by a rich set of grave goods (Fontana, 2006) and some Bronze Age dwelling structures.

The Early Mesolithic (Sauveterrian) evidence includes a paved area made of local tufa slabs (SU 14), delimited by an arrangement of blocks of dolomite stones (SU 33) and a sub-circular structure, 


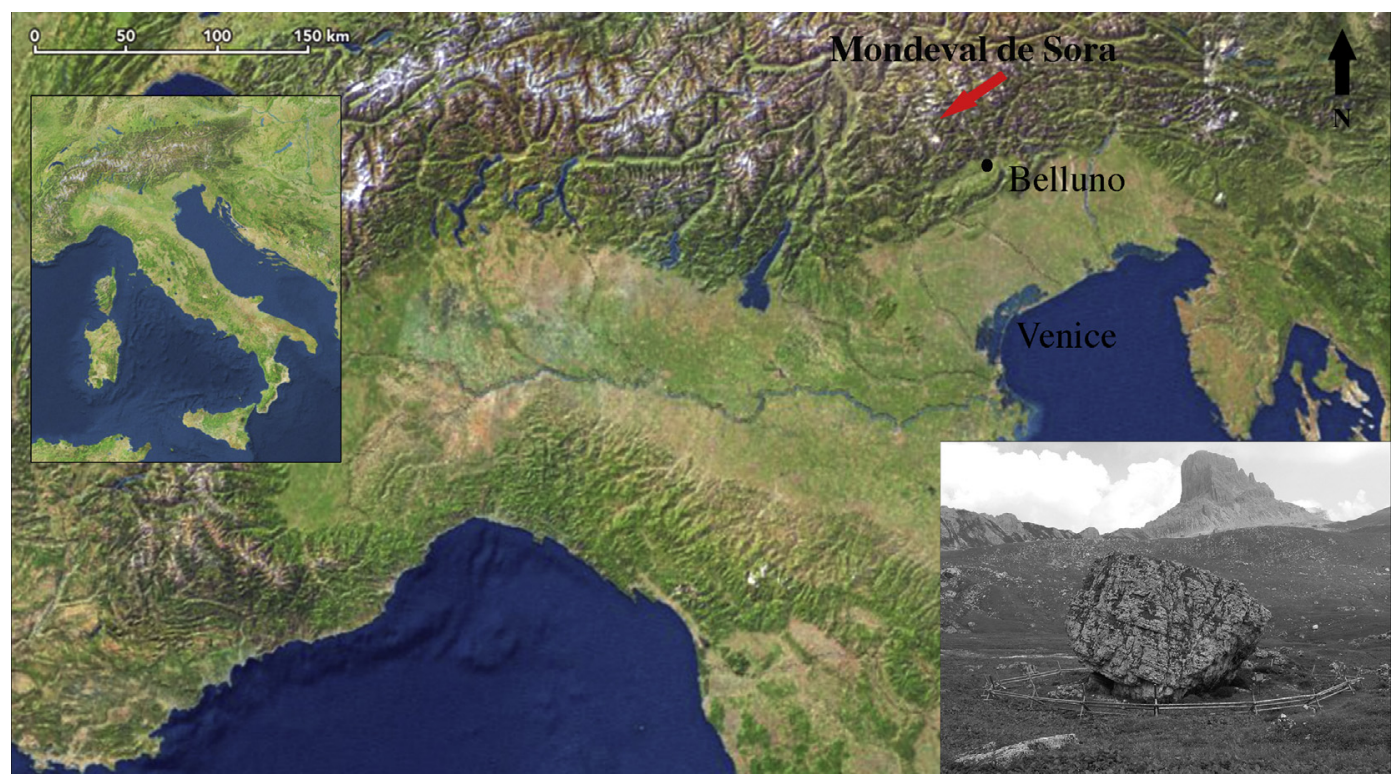

Fig. 1. Mondeval de Sora VF1. Location of the site in northern Italy; Sector I is on the right of the erratic boulder.

interpreted as a hearth (SU 32) (Alciati et al., 1992; Fontana and Vullo, 2000; Peretto et al., 2004). Two anthropic layers covered these structures being located respectively in the inner (SU 8) and in the external part of the site (SU 31) and the latter underlying the first one (Fig. 2). Stratigraphic Unit 8, is constituted by a $20 \mathrm{~cm}$ deep layer, rich in charcoals, bones, and lithic artefacts and extended about $18 \mathrm{~m}^{2}$ with a thickness that progressively increased toward the outside of the shelter (from $5 \mathrm{~cm}$ to $20 \mathrm{~cm}$ ); it covered the paved area tufa slabs (SU 14), part of the arrangement of dolomite blocks
(SU 33) and in some parts sterile layers. Its original extension has been altered along the north side by levelling works of the ground slope performed in historical times.

The lithic assemblage from SU 8 is composed of approximately 20,000 items (among which were 46 cores, 1391 retouched artefacts and 1206 microburins) and is dominated by the most common Sauveterrian typological elements such as microlith fragments, triangles, backed points and crescents. The provenance of lithic raw materials can be mostly traced within the Jurassic and Cretaceous

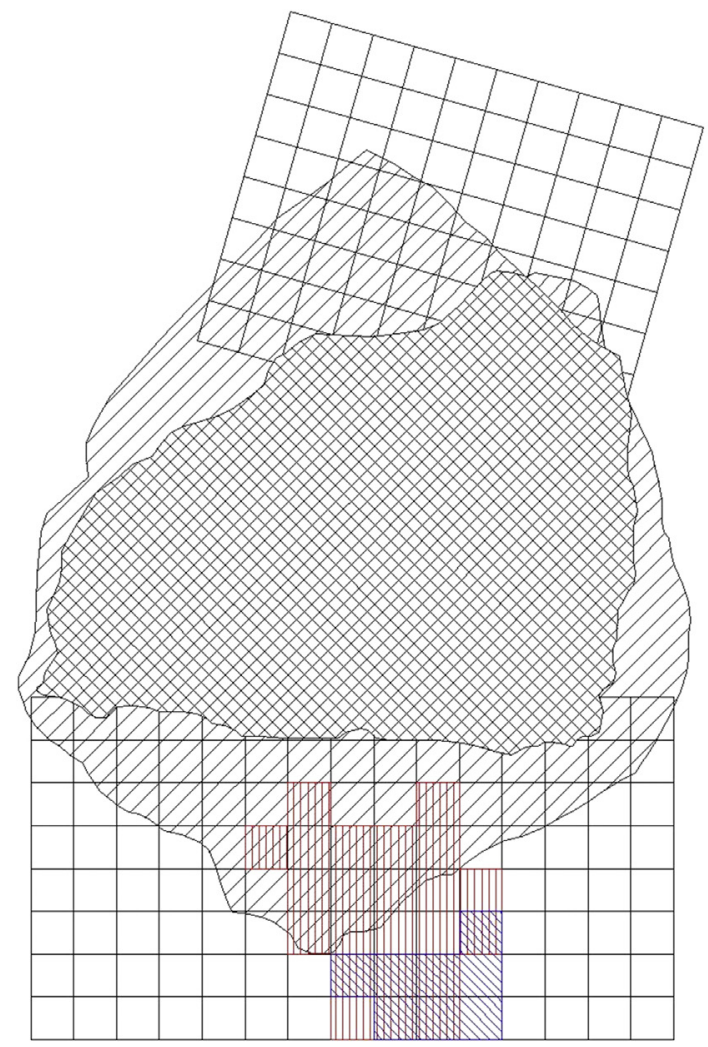

\section{Sector III}

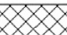

Base of the boulder

Overhang of the boulder

SU8

SU31

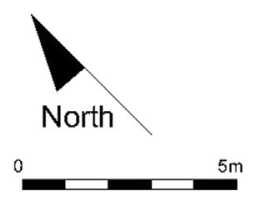

\section{Sector I}

Fig. 2. Mondeval de Sora VF1. Explored area of SSUU 8 and 31 within sector I. 
formations cropping out along the pre-Alpine belt, about $20 \mathrm{~km}$ from the site as the crow flies. Preliminary studies support that these were mainly imported from the Piave valley-bottom within an embedded procurement system by the groups that occupied the area of Mondeval in the summer season. Strictly local Alpine cherts (Livinallongo formation and local conglomerates) were also exploited, along with hyaline quartz, the origin of which can be traced further north in the metamorphic formations of the inner Alps. The application of use-wear analysis to a sample of microliths and tools has documented the presence of edge damage that could be connected to hunting activities and animal carcasses processing such as muscle mass removal and skin treatment. Some impact traces have also been recognized on backed and truncated points (Vullo et al., 1999; Fontana and Vullo, 2000; Guerreschi et al., 2002; Fontana et al., 2009a). On the basis of the spatial analysis and the technological study of the lithic assemblage SU 8 has been interpreted as "a complex multifunctional zone within a larger residential site, represented by the total area protected by the overhang of the boulder" (Fontana and Vullo, 2000, p. 208).

Stratigraphic Unit 31, located in the external part of the site, was constituted by a light brown sandy-silty matrix and characterized by numerous faunal remains. Its extension was approximately 5.05 square meters and covered the dolomia blocks arrangement. The lithic assemblage amounted to a total of 8680 artefacts but most of them (6516) were smaller than $5 \mathrm{~mm}$ and 1330 totally burned and therefore undeterminable. The spatial distribution showed a trend towards the concentration of the finds in the outer part of this SU with respect to the position of the boulder overhang in correspondence of the area where the layer becomes thicker; however the archaeological material did not present any particular distribution within this SU that could suggest that specific activities had taken place in this area of the site (Guerreschi et al., 2002). Stratigraphic unit 31 has therefore been interpreted as the "result of the accumulation of waste products which had been produced elsewhere, at least as far as the lithic assemblage is concerned" (Guerreschi et al., 2002); it is the result of a "chaotic" concentration of materials.

The chronological and cultural attribution of both levels and structures were made on the basis of the techno-typological characteristics of the abundant lithic industry and a radiocarbon date obtained on a charcoal remain from SU 8 (9185 \pm 240 BP, 110999693 cal BC, GX-21788).

Pollen analysis carried out in the nearby Alpe Fedèra (Soldati et al., 1997) has allowed the presence of a wooded environment dominated by Picea-Pinus to be identified, which established starting from the late Preboreal period and the beginning of the Boreal (Soldati et al., 1997). Therefore, during the early Mesolithic the site was probably situated in an area of transition between the open Alpine grassland and the forest, near the tree-line. The position of the settlement thus allowed the Mesolithic hunter-gatherers to exploit a wide variety of resources offered by this ecotone (Fontana et al., 2009a).

\section{Materials and methods}

The faunal assemblages that have been analysed come from two stratigraphic units of the Sauveterrian deposits of the I excavated sector located under the side of the erratic boulder facing south-east (Fontana et al., 2009a). The assemblages are characterised by a high degree of fragmentation due to both anthropic activities and postdepositional factors (Beherensmeyer, 1978; Lyman, 1994; Stiner et al., 1995; Bennett, 1999; Outram, 2001). The archaeozoological studies have been carried out by analysing the entire assemblages and separating the unidentified remains for size classes wherever it was possible. All the bone fragments were measured and osteological measurements were collected following Von den Driesch (1976) also. Estimation of the age at death and age classes were calculated on the basis of tooth eruption and use-wear of teeth. A taphonomic analysis has been carried out on all the specimens in order to define the preservation degree of the bone surfaces and to distinguish the edaphic and anthropic modifications referring to Beherensmeyer (1978), Beherensmeyer et al. (1986), Olsen and Shipman (1988), Malerba and Giacobini (1993), Lyman (1994), Giacobini (1995, 1996), Blasco et al. (2008), Domìnguez-Rodrigo et al. (2009). Carnivore and rodent marks were distinguished following to Binford (1981), Brain (1981), Giacobini (1995), Cilli et al. (2000). Burnt bones were recognized too (Bennett, 1999; Asmussen, 2008). A stereo-microscope Leica S6D $(6 \times-40 \times$ magnification), with integrated digital camera EC3 was used. A detailed observation with a scanning electron microscope has been done on replicas of the marks, produced with silicon moulds (Provil Novo ${ }^{\circledR}$ Fast Light Set, Heraeus Kulzer) and epoxy resin (Araldite ${ }^{\circledR}$ LY554, Hardener HY956). The identification of intentional fresh bone fracturing for marrow extraction, post-depositional fractures and manufacturing marks was done (Sadek-Kooros, 1972; Myers et al., 1980; Shipman et al., 1984; Villa and Mahieu, 1991; Blasco Sancho, 1992; Lyman, 1994; Anconetani and Peretto, 1996; Peretto et al., 1996).

With regards to spatial analysis, the entire faunal database could be associated with the excavation grid with the use of a GIS system (QGIS 2.12.3 - Lyon). The recovery of materials during excavation was carried out on squares measuring $1 \mathrm{~m} \times 1 \mathrm{~m}$. These squares were further sub-divided into nine quadrants of $33 \mathrm{~cm}$ each (numbered 1 to 9 ), which enabled a more detailed positioning of the remains (Turrini et al., 2014, 2015). Then, distribution maps were elaborated and processed, based on the quantile method.

\section{The faunal assemblages of the I sector of VF1}

\subsection{The composition of the assemblage SU 8}

The macrofaunal assemblage from SU 8 is composed of 83,711 remains. The 2284 specimens examined for this study consist of identified remains and the unidentified fragments longer than $2 \mathrm{~cm}$. The identified specimens represent $26 \%$ of the sample. Regarding the composition of the faunal assemblage, on the basis of the Number of Identified Specimens and the Minimum Number of Individual (Table 1), red deer is the most represented species, followed by ibex, chamois and roe deer. Some remains of wild boar have been identified, while carnivores such as wolf, fox and bear, are scarce. The presence of a tooth and a third phalanx of aurochs has been confirmed (Table 1).

Age at death has been estimated on the basis of the degree of dental eruption and attrition, and on the state of ossification of long bones, revealing that most taxa belong to adults, although some young individuals are present in all the species identified, except for the aurochs and the wolf.

Red deer is represented by 12 individuals: distributed over 4 juveniles and 8 adults while ibex is represented by 2 juveniles and 6 adults. The presence of deciduous teeth of red deer ( 4 left $\mathrm{i}_{2}$ ) and ibex $\left(2 D^{2}\right.$ and $\left.1 d_{3}\right)$ can be attributed to young individuals of $12-16$ months old, hunted in the late spring/beginning of summer.

As far as the composition of skeletal elements is concerned, red deer and ibex are represented by almost all the anatomical elements, showing the introduction of whole carcass of these animals into the site (Table 2). The under-representation of the post-cranial skeleton of these animals is probably due to intentional bone fracturing aimed at extracting the marrow.

\subsection{The composition of the assemblage SU 31}

The faunal assemblage from sector I SU 31 is composed of 33,051 faunal remains. Majority of the remains are unidentified fragments smaller than $2 \mathrm{~cm}$ (89\%), while only 3445 remains are longer than 
Table 1

Mondeval de Sora I sector VF1. Faunal composition of SU 8 and SU 31.

\begin{tabular}{|c|c|c|c|c|c|c|}
\hline \multirow[b]{2}{*}{ Taxon } & \multicolumn{3}{|l|}{ SU8 } & \multicolumn{3}{|l|}{ SU 31} \\
\hline & NISP & \%NISP & MNI & NISP & \%NISP & MNI \\
\hline Canis lupus & 1 & 0.16 & 1 & & & \\
\hline Vulpes vulpes & 1 & 0.16 & 1 & & & \\
\hline Ursus arctos & 11 & 1.85 & 2 & 6 & 1.48 & 1 \\
\hline Sus scrofa & 12 & 2.02 & 2 & 2 & 0.49 & 1 \\
\hline Cervus elaphus & 336 & 56.66 & 12 & 225 & 55.69 & 11 \\
\hline Capreolus capreolus & 20 & 3.37 & 5 & 6 & 1.48 & 1 \\
\hline Cervidae & 2 & 0.32 & & 65 & 16.08 & \\
\hline Capra ibex & 153 & 25.9 & 8 & 65 & 16.08 & 4 \\
\hline Rupicapra rupicapra & 31 & 5.22 & 3 & 11 & 2.72 & 1 \\
\hline Capra sp. & 24 & 4.02 & 4 & 15 & 3.76 & \\
\hline Bos primigenius & 2 & 0.32 & 1 & & & \\
\hline Bovidae & & & & 9 & 2.22 & \\
\hline Total identified & 593 & 100 & 39 & 404 & 100 & 19 \\
\hline Large sized Ungulata & 115 & & & 99 & & \\
\hline Medium sized Ungulata & 32 & & & 25 & & \\
\hline Small sized Ungulata & 23 & & & 30 & & \\
\hline Ungulata & 99 & & & 372 & & \\
\hline Total Ungulata & 269 & & & 526 & & \\
\hline Total & 862 & & & 930 & & \\
\hline Unidentified $>2 \mathrm{~cm}$ & 1422 & & & 2515 & & \\
\hline Total remains $>2 \mathrm{~cm}$ & 2284 & & & 3445 & & \\
\hline Unidentified $<2 \mathrm{~cm}$ & 81,427 & & & 29,606 & & \\
\hline Total remains & 83,711 & & & 33,051 & & \\
\hline
\end{tabular}

$2 \mathrm{~cm}$ and could be examined for this study (Rinaldi, 2010). The identified remains are 404 in total and amount to $27 \%$ of the sample. The remains determined only at anatomical level are mainly teeth, limb bones (in particular metapodia), carpals and phalanges. Teeth represent more than $60 \%$ of the identified specimens. Fragments of ribs, vertebrae and pelvis are less represented.

The assemblage appears to be composed almost exclusively of ungulates and among them red deer is the most frequent species

Table 2

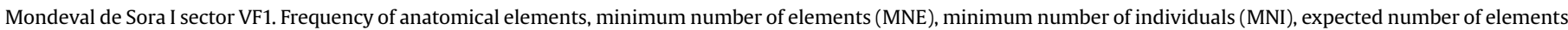
(eNE) and survival index (MNE/eNE) for red deer and ibex.

\begin{tabular}{|c|c|c|c|c|c|c|c|c|c|c|c|c|c|c|c|c|c|c|c|c|}
\hline & \multicolumn{10}{|l|}{ SU8 } & \multicolumn{10}{|c|}{ SU 31} \\
\hline & \multicolumn{5}{|c|}{ Cervus elaphus } & \multicolumn{5}{|c|}{ Capra ibex } & \multicolumn{5}{|c|}{ Cervus elaphus } & \multicolumn{5}{|c|}{ Capra ibex } \\
\hline & NISP & MNE & MNI & eNE & MNE/eNE & NISP & MNE & MNI & eNE & MNE/eNE & NISP & NME & MNI & eNE & $\mathrm{MNE} / \mathrm{eNE}$ & NISP & MNE & MNI & eNE & MNE/eNE \\
\hline Antler & 10 & 1 & 1 & & & & & & & & 4 & 1 & 1 & & & & & & & \\
\hline Horn & & & & & & & & & & & & & & & & 1 & 1 & 1 & 8 & 0.12 \\
\hline Skull & 5 & 1 & 1 & 12 & 0.08 & & & & & & 1 & 1 & 1 & 11 & 0.09 & & & & & \\
\hline Mandible & 3 & 2 & 2 & 24 & 0.08 & & & & & & 5 & 3 & 2 & 22 & 0.13 & & & & & \\
\hline Deciduous teeth & 27 & 22 & 4 & & & 3 & 3 & 2 & & & 8 & 6 & 2 & & & & & & & \\
\hline Upper teeth & 106 & 75 & 6 & & & 29 & 27 & 4 & & & 65 & 48 & 9 & & & 14 & 12 & 2 & & \\
\hline Lower teeth & 118 & 83 & 8 & & & 71 & 53 & 6 & & & 53 & 42 & 5 & & & 15 & 11 & 4 & & \\
\hline Teeth undet. & 4 & & & & & & & & & & 21 & & & & & 1 & & & & \\
\hline Atlas/Epistropheus & 1 & 1 & 1 & 24 & 0.04 & & & & & & 2 & 1 & 1 & 11 & 0.09 & & & & & \\
\hline $\begin{array}{l}\text { Scapula } \\
\text { Ribs }\end{array}$ & & & & & & 2 & 2 & 2 & 16 & 0.12 & & & & & & 3 & 2 & 1 & 8 & 0.25 \\
\hline Humerus & 2 & 2 & 2 & 24 & 0.08 & 1 & 1 & 1 & 16 & 0.06 & 5 & 3 & 2 & 22 & 0.13 & 3 & 1 & 1 & 8 & 0.12 \\
\hline Radius & 2 & 2 & 2 & 24 & 0.08 & 1 & 1 & 1 & 16 & 0.06 & 1 & 1 & 1 & 22 & 0.04 & & & & & \\
\hline Ulna & 1 & 1 & 1 & 24 & 0.04 & & & & & & 1 & 1 & 1 & 22 & 0.04 & & & & & \\
\hline Carpals & 10 & 10 & 3 & 144 & 0.06 & 10 & 8 & 2 & 96 & 0.08 & 7 & 7 & 2 & 132 & 0.05 & 7 & 7 & 2 & 48 & 0.14 \\
\hline Metacarpals & 1 & 1 & 1 & 24 & 0.04 & 1 & 1 & 1 & 16 & 0.06 & 6 & 3 & 2 & 22 & 0.13 & & & & & \\
\hline Innominate & & & & & & & & & & & & & & & & 1 & 1 & 1 & 8 & 0.12 \\
\hline Femur & & & & & & & & & & & 7 & 4 & 4 & 22 & 0.18 & 3 & 2 & 1 & 8 & 0.25 \\
\hline Patella & 1 & 1 & 1 & 24 & 0.04 & 2 & 2 & 2 & 16 & 0.12 & & & & & & & & & & \\
\hline Tibia & 1 & 1 & 1 & 24 & 0.04 & 1 & 1 & 1 & 16 & 0.06 & 7 & 5 & 4 & 22 & 0.22 & 3 & 2 & 2 & 8 & 0.25 \\
\hline Fibula & & & & & & & & & & & & & & & & & & & & \\
\hline Malleolus & & & & & & & & & & & & & & & & 1 & 1 & 1 & 8 & 0.12 \\
\hline Tarsal & 5 & 5 & 2 & 72 & 0.06 & 3 & 3 & 1 & 48 & 0.06 & 2 & 2 & 1 & 66 & 0.03 & & & & & \\
\hline Astragalus & & & & & & 3 & 3 & 2 & 16 & 0.18 & 1 & 1 & 1 & 22 & 0.04 & & & & & \\
\hline Calcaneus & 3 & 3 & 2 & 24 & 0.12 & & & & & & 2 & 2 & 1 & 22 & 0.09 & & & & & \\
\hline Metatarsals & 1 & 1 & 1 & 24 & 0.04 & & & & & & 6 & 5 & 3 & 22 & 0.22 & 4 & 2 & 1 & 8 & 0.25 \\
\hline Metapodials & 1 & & & & & & & & & & & & & & & 2 & & & & \\
\hline I phalanx & 11 & 6 & 1 & 96 & 0.06 & 11 & 8 & 1 & 64 & 0.12 & 5 & 3 & 1 & 88 & 0.03 & 2 & 1 & 1 & 32 & 0.03 \\
\hline II phalanx & 13 & 8 & 1 & 96 & 0.08 & 8 & 5 & 1 & 64 & 0.07 & 6 & 4 & 1 & 88 & 0.04 & 2 & 1 & 1 & 32 & 0.03 \\
\hline III phalanx & 10 & 4 & 1 & 96 & 0.04 & 7 & 3 & 1 & 64 & 0.04 & 2 & 2 & 1 & 88 & 0.02 & 3 & 1 & 1 & 32 & 0.03 \\
\hline Vestigial phalanx & & & & & & & & & & & 5 & 5 & 1 & & & & & & & \\
\hline Sesamoids & & & & & & & & & & & 3 & 3 & 1 & & & & & & & \\
\hline Total & 336 & 220 & 12 & & & 153 & 113 & 8 & & & 225 & 153 & 11 & & & 65 & 45 & 4 & & \\
\hline
\end{tabular}


followed by ibex (Table 1 ). If the remains attributed to large and medium sized ungulates are included, the frequencies of both red deer and ibex consequently increase and therefore, they represent the most hunted preys. Hunted animals also included chamois and roe deer. Among the other identified species, there are brown bear (6 remains) and wild boar (only 2 remains).

Considering the age at death of the two most represented taxa, all age classes have been recognized for red deer while only juveniles and adults for ibex. Wild boar is attested to solely by juveniles (1-2 MNI, 6-12 months; Table 1) and other taxa similarly, only by adults.

In the case of red deer, body part representation indicates that almost all the elements are represented, suggesting that whole carcasses were introduced into the site.

Antler, skull and mandible fragments are present but complete and isolated teeth are the most represented element (Table 2; 65\% of red deer remains). Moreover, teeth have been broken by postdepositional factors and many small fragments which were recovered have been included in Cervidae. Majority of the teeth belong to adults but several deciduous teeth and unworn molars have been collected. Completely worn third molars are also present. Documented teeth measurements revealed significant differences in size attesting to the presence of large sized males and small to medium sized females.

Few complete vertebrae have been preserved while the rest of them are very fragmented. They have been included in the large sized ungulate and unidentified remains.

The appendicular skeleton is represented by both elements of the fore (20 remains) and hind (25 remains) limbs. Long bones are represented mainly by diaphyseal fragments (approximately 99) and by epiphyseal portions ( 5 humeri, 1 radius-ulna, 6 metacarpals, 7 femurs, 7 tibiae and 6 metatarsals), carpals (7) and tarsals (5), phalanges (18). In terms of laterality, the right side slightly outnumbers the left one.

Age at death and minimum number of individuals have been estimated based on upper molar teeth as they are the most numerous with respect to the lower teeth and limb bones. Red deer is represented by 11 individuals: distributed over 2 juveniles (left upper D3), 7 adults (upper left third molar) and 2 senile (very worn - upper left third molar). The tooth wear suggests the presence of 2 one-year old individuals and 7 prime adults (3-6 years old), killed at the beginning of summertime.

With regard to ibex, body part representation indicates that only part of the carcasses were introduced into the site. Among the 65 identified remains, $48 \%$ are teeth. The only bones identified comprise one fragment of scapula, carpals, metatarsals and phalanges. One fragment of horn has been recovered. The right side elements dominate the left ones.

Totally, 25 remains attributable to medium sized ungulates could be referred to ibex ( 7 fragmented teeth; pelvis (1); diaphyses of femur (3), humerus (3), tibia (4), and metapodium (4) (Table 1).

Age at death and minimum number of individuals have been calculated based on right lower third molar which allowed to estimate 4 adults.

The presence of juveniles, for red deer (one-year old individuals) and wild boar (6-12 months), suggests that the site was occupied from the late spring and during the summertime. During this season, the red deer, a species typically linked to wooded environments, usually migrates to forests located at higher altitudes.

\subsection{Taphonomical analysis (SSUU 8 and 31)}

Taphonomical analyses have been carried out in order to investigate anthropic modifications and to distinguish them from those produced by other factors (Table 3 ).

The assemblages are characterized by a high degree of fragmentation caused by both anthropic activity and post-depositional
Table 3

Mondeval de Sora I sector VF1. Frequency of the different categories of bone surface modifications.

\begin{tabular}{lrrrrr}
\hline Edaphic modification NR $>2 \mathrm{~cm}$ & \multicolumn{2}{c}{ SU 8 TNR 2284 } & & \multicolumn{2}{c}{ SU 31 TNR 3445 } \\
\cline { 2 - 3 } \cline { 5 - 6 } \cline { 5 - 6 } & NR & \%TNR & & NR & \%TNR \\
\hline Rodent marks & 20 & 0.8 & & 9 & 0.3 \\
Carnivore gnawing & 4 & 0.2 & & 14 & 0.4 \\
Root etching & 106 & 4.6 & & 251 & 7.3 \\
Weathering & 174 & 7.6 & & 132 & 3.8 \\
Erosion & 102 & 4.5 & & 235 & 6.9 \\
Exfoliation & 23 & 1.0 & & 63 & 1.8 \\
Anthropic modification NR $>\mathbf{2}$ cm & & & & \\
Burned & 74 & 3.2 & & 183 & 5.3 \\
Cut-marks & 79 & 3.4 & & 32 & 0.9 \\
Scraping & 3 & 0.1 & & 6 & 0.2 \\
Intentional bone breakage & 208 & 9.1 & & 465 & 13.5 \\
Notches & 19 & 0.8 & & 19 & 0.5 \\
Percussion cones & 153 & 6.7 & & 35 & 1.0 \\
Flake scars & - & - & & 3 & 0.1 \\
Detachment & 81 & 3.5 & & 18 & 0.5 \\
\hline
\end{tabular}

factors. Evidence of exfoliation, erosion and weathering cracks has been recognised on the bone surfaces. A fair number of remains are impacted by root-etching, especially in SU 31 (Table 3). Rodent and carnivore marks are rare in both the SSUU, revealing their occasional occupation of the site. However, they could have contributed to the dispersal of the osteological remains.

Despite the high fragmentation of the bones, the degree of preservation of the bone surfaces is fairly good and has enabled recognition of cut-marks related to slaughtering.

Within the bone samples analysed, fragments yielding butchery marks amount to about 3.4\% of the total number of remains in SU 8 and $0.9 \%$ in SU 31 (Table 3). On several remains cut-marks, which suggest that butchery probably occurred within the site, were found. Most cut-marks were observed on unidentified specimens, especially on shaft fragments. Regarding the animal carcass exploitation, it was not possible to assess the stages of the butchery process for any species because of the low number of identified remains with diagnostics traces. The exploitation of the carcasses seems rather intensive and designed to recover all the components. Nonetheless, skinning and disarticulation marks produced by the sharp edge of a lithic tool have been detected on a few remains of red deer and ibex (scapula, humeri, phalanges, metapodia and astragalus) in both the SSUU (Table 3) and on one femur diaphysis of bear in SU 31. Cut-marks are present on 3 red deer (4.2\% of NISP) and 2 ibex ( $4 \%$ of NISP) remains in SU 8 and on 4 red deer and 3 ibex remains in SU 31 (5.4\% and 1.2\% of NISP excluding teeth and antler/ horn) respectively. Cut-marks and scraping are present on a few long bones of medium and large sized ungulates and can be attributed to muscle mass removal actions (Fig. 3). SEM analysis has been carried out in order to identify the micromorphological characteristics referable to the sliding edge of a lithic tool. Cut marks are also found on the sesamoid and metapodia mainly documenting actions of disarticulation.

Intentional bone fracturing is the best represented anthropic modification as it is documented by the presence of notches, impact points, percussion cones and cortical and medullar detachments (Table 3). The high quantity of percussion cones in SU 8 confirms an intensive intentional bone fracturing, which occurred at the site. A fair amount of fragments, but also some of greater size, sometimes bearing cut-marks, shows evidence of burning. They may have been produced not only from food consumption, but also from waste disposal. Burnt bones are well documented. Considering the faunal assemblages coming from the two SSUU in their entirety, they amount to 21\% for SU 8 (NR 17,713) and to 15\% (NR 4819) for SU 31.

Moreover, as it has been suggested by the discovery of a fragment of a metapodium bearing numerous traces of longitudinal 

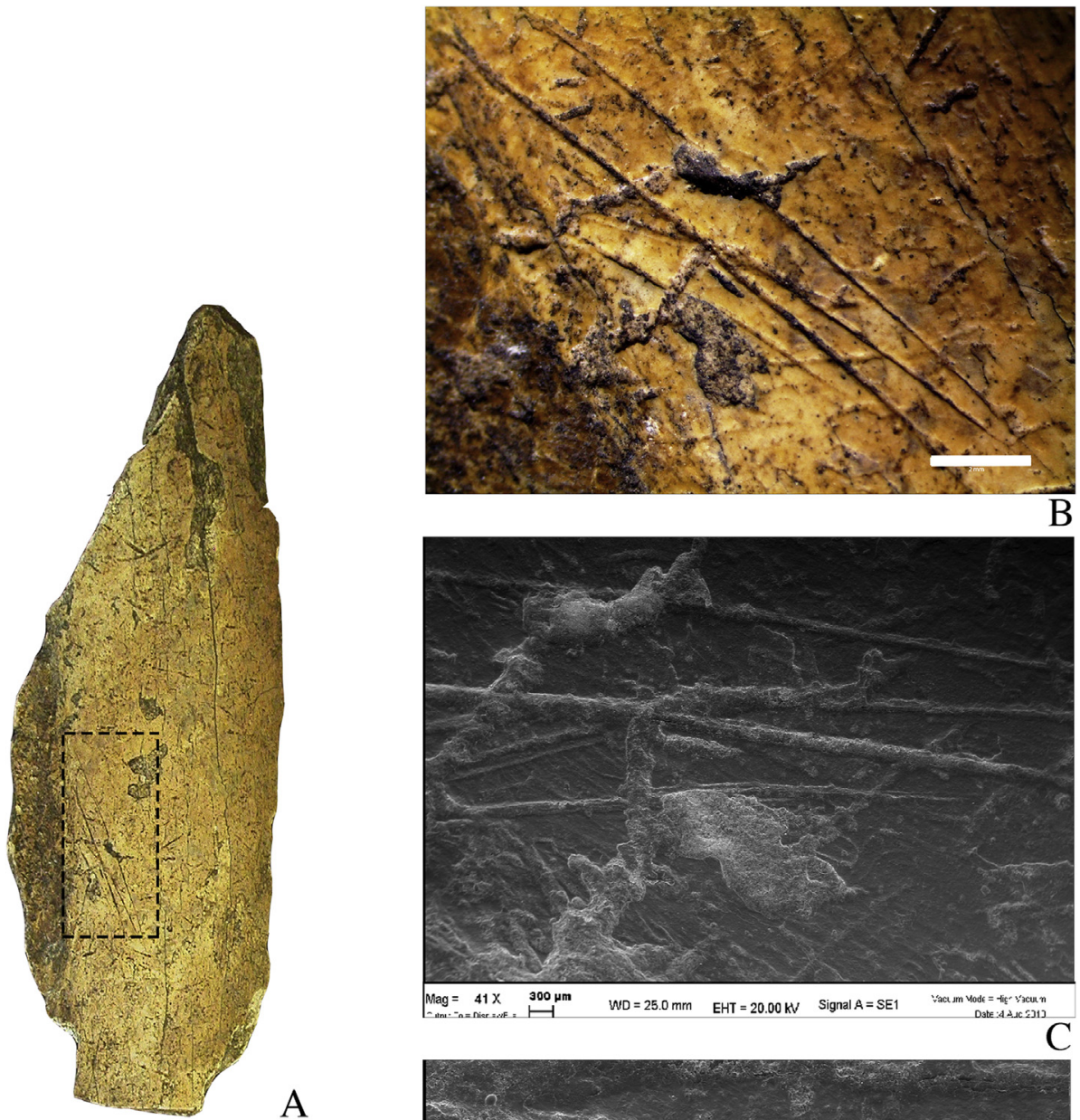

A
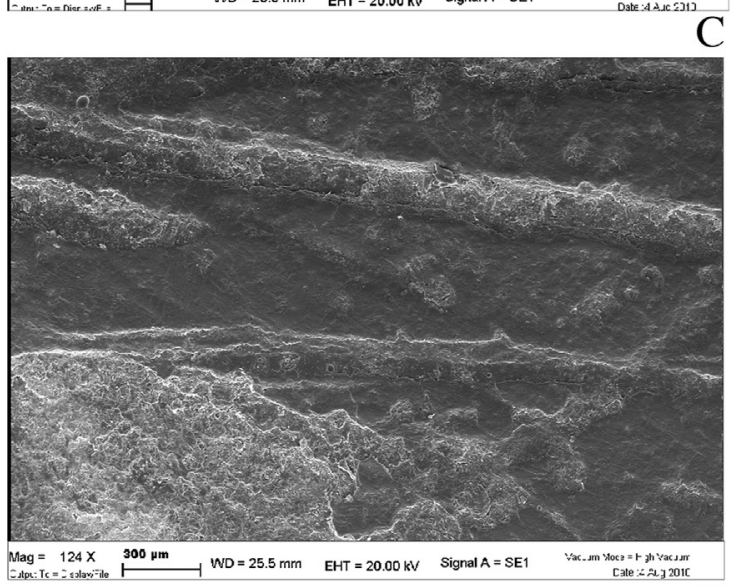

$\mathrm{D}$

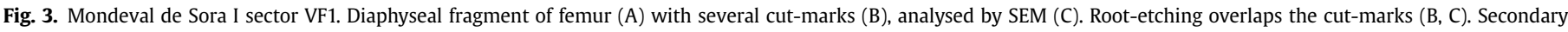
striations made by a lithic tool are visible inside the main sulcus (D). (A-B: bar scale $1 \mathrm{~cm}$ ).

scraping, bone processing operations probably also took place inside the site. The fragment, scraped on three sides and almost $5 \mathrm{~cm}$ in length, could represent a manufacturing waste or may have been part of an unfinished tool (Fig. 4). Moreover, numerous fragments of burnt antler could be also related to hard animal material manufacturing, involving use of fire for production of tools or ornamental objects.

\subsection{Spatial distribution}

Spatial distribution of the faunal remains has been made for both SSUU 8 and 31 and aimed to highlight any possible areas of anthropic activity. Both SSUU present, in the different quadrants, a variable thickness that increases from the inner to the outer part of the site (Figs. 5 and 6).

This analysis shows a concentration of identified specimens in the middle part of the SU 8 (Fig. 5) while the unidentified remains are located in the surrounding zones with some concentration of fragments smaller than $2 \mathrm{~cm}$ (Turrini et al., 2014, 2015).

The overall distribution of faunal remains of SU 31 points to a substantially non-homogenous distribution within the analysed areas: in areas with higher concentration of finds, the fragmentation is greater and the finds of less than $2 \mathrm{~cm}$ are more numerous (Fig. 6).

This kind of fragmentation is not associated with fireplaces but with post-depositional factors. In fact, burnt remains are invariably 

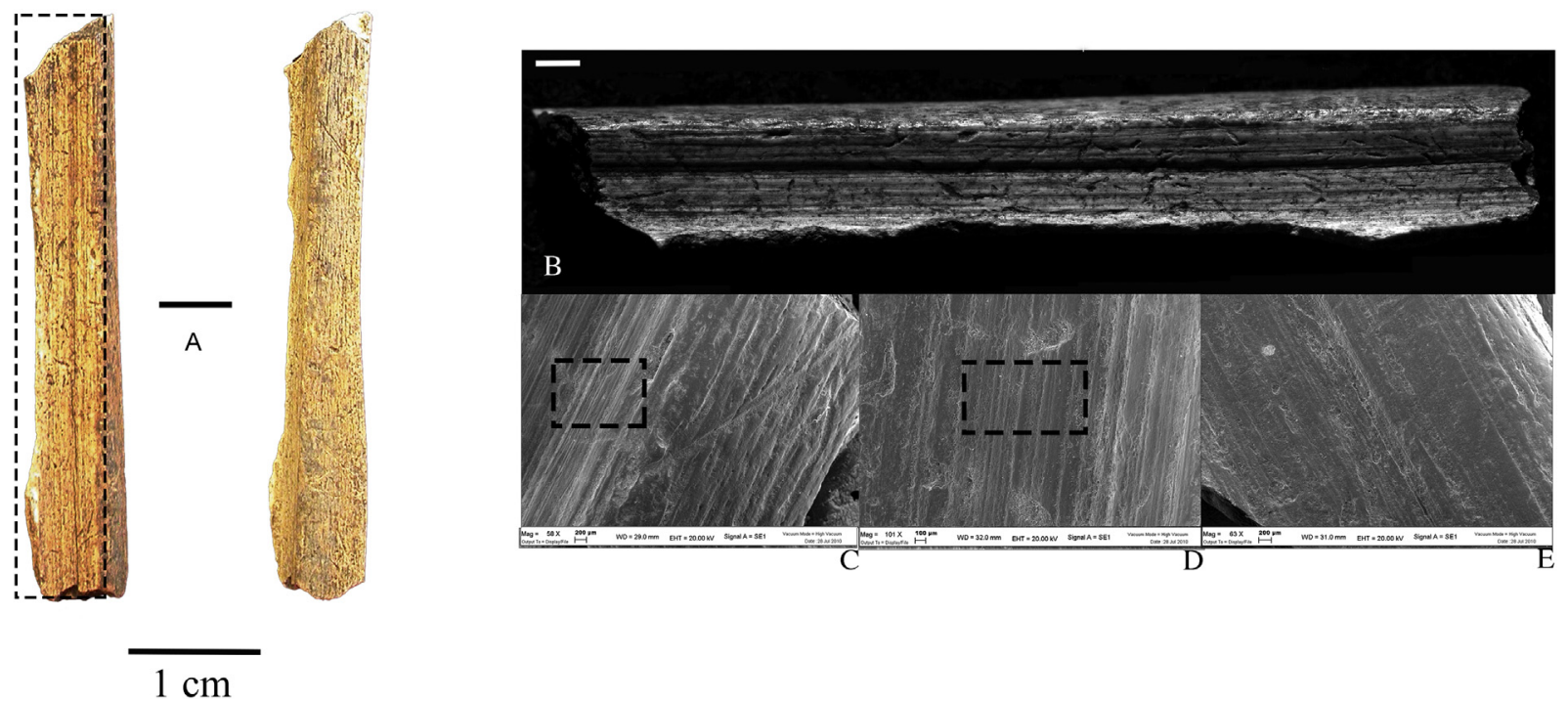

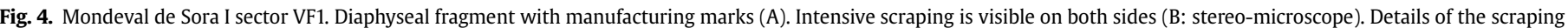
with SEM (C-E). (A-B: bar scale $1 \mathrm{~cm})$.

found mixed with unburnt remains and seem to be derived rather from the accumulation of waste resulting from the cleaning of hearths (Turrini et al., 2015). They can thus be interpreted as an accumulation of successive occupations over a course of time. The distribution of remains with respect to edaphic processes allows to state that the natural factors have acted with the same intensity on both SSUU.

Regarding the distribution of various species present in the assemblage, it was possible to carry out spatial analysis only on the remains of deer and ibex. Other identified species did not find particular relevance at the distribution level as their remains were scarce in quantity.
In fact, the distribution of deer and ibex remains follows the overall distribution of faunal remains (Figs. 5 and 6). Concentrations, if any, coincide with the quadrant where there is a higher frequency of remains, which is influenced by the thickness of the layer. The anatomical distribution of deer and ibex remains and that relating to carcass processing (fractures and cut marks) were found in no significant accumulations. Instead, the presence of a large number of percussion cones in the inner part of the site (153 in SU; Table 3), compared to those found in the outer part of the site (35 in SU31; Table 3) suggests that the fracturing of bones had to take place below the overhang of the boulder. Moreover, while the inner part appears to be rich in fragments of small size and in epiphyseal portions (Fontana et al., 2009a), the

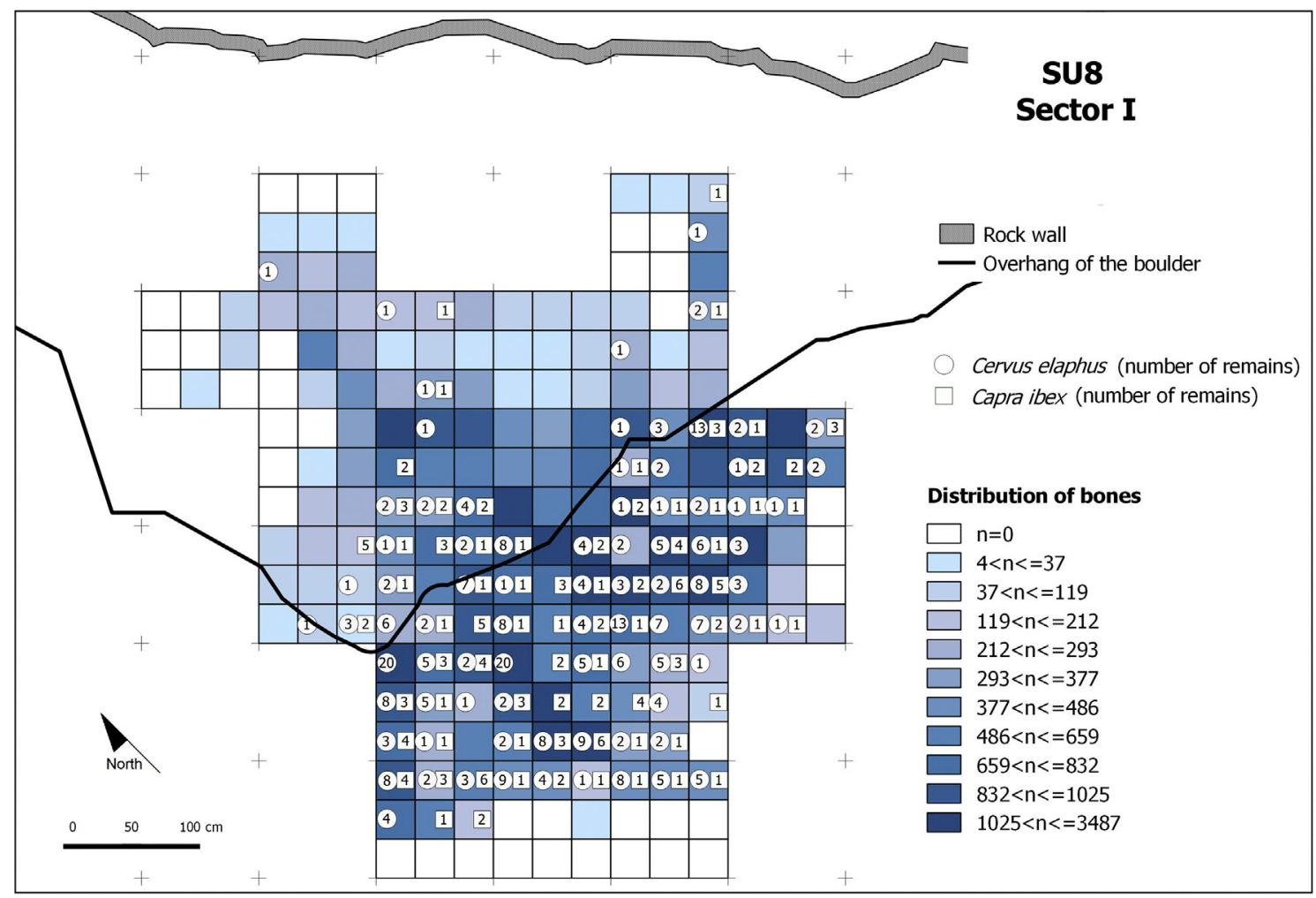

Fig. 5. Mondeval de Sora I sector VF1. Distribution of the entire assemblage and identified faunal remains of red deer and ibex in SU 8. 


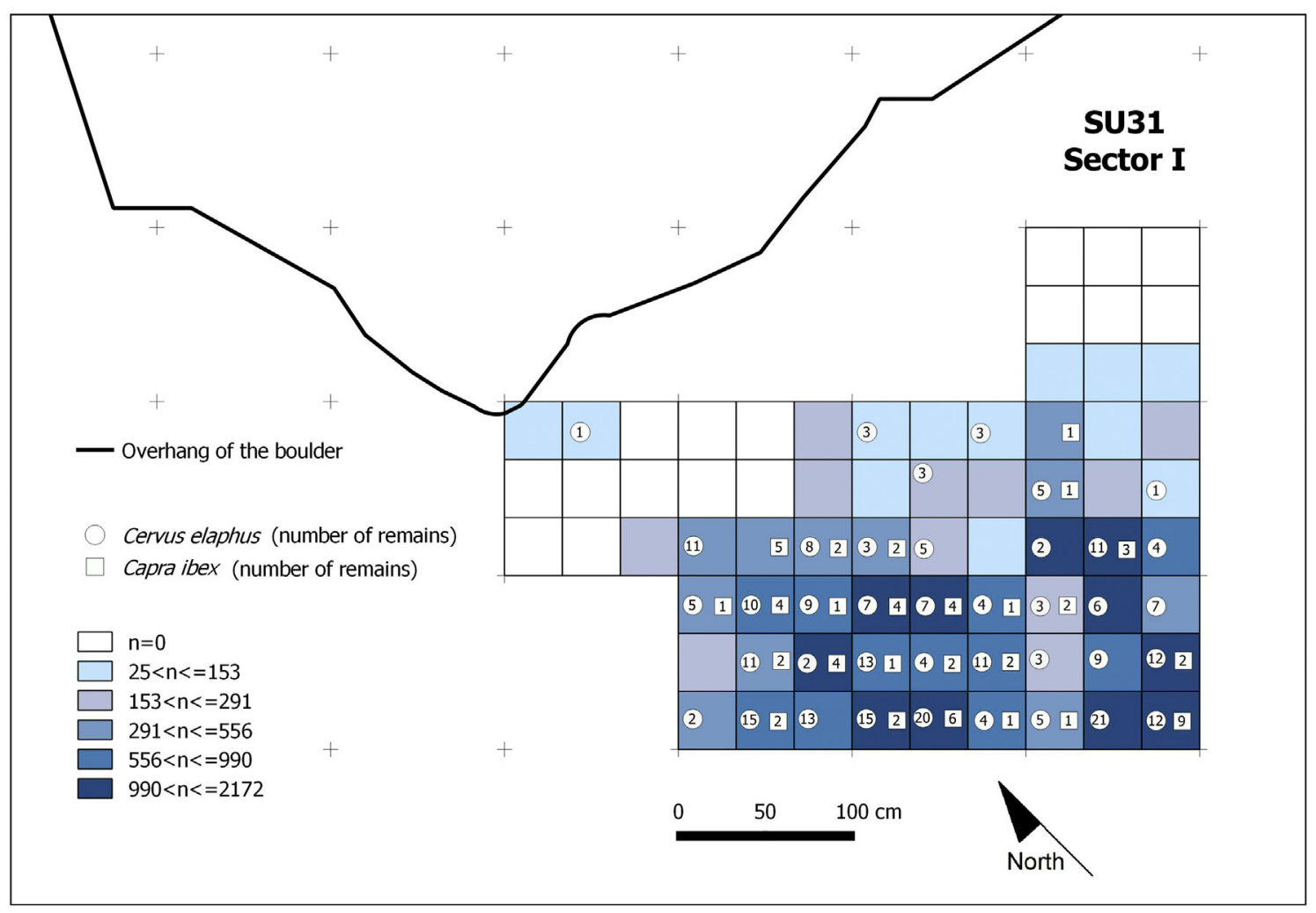

Fig. 6. Mondeval de Sora I sector VF1. Distribution of the entire assemblage and identified faunal remains of red deer and ibex in SU 31.

external part, according to the spatial distribution maps, also presents a large number of intentionally fractured diaphyses found to be concentrated mainly in some points. These concentrations could therefore, likely, be represented by the larger remains of exploited carcasses, thrown outside during slaughtering process.

\section{Discussion and conclusion}

Red deer is the most hunted taxon in both of the analysed SSUU on the basis of the NISP and MNI, followed by ibex that is most represented in SU 8 than SU 31 (Table 2).

The analysis of the survival coefficient (MNE/eNE, Table 2) demonstrates the low presence of post-cranial elements due to the high degree of fragmentation that has strongly affected both assemblages and it was not useful to interpret the carcasses exploitation. Only teeth are well represented and allowed the estimation of number of prey. Some qualitative observations can be made since among the large ungulate remains, a huge amount of ribs, vertebrae and diaphyseal fragments, that could be referred to red deer, are present. Medium sized fragments include mostly diaphyseal fragments. This differential anatomical composition could document the introduction of entire red deer carcasses and only portions of ibex within the site documenting a major interest in red deer hunting. Taphonomical analysis has revealed that changes in temperature and humidity, combustion and trampling have strongly influenced both the assemblages overlapping with intense traces of intentional bone fracturing left behind by human activity in both units. This allows to assert that the high degree of fragmentation of the remains is mainly due to anthropic intervention. Such an assertion is testified by the large number of percussion cones, mostly in SU8, and various kind of repetitive fracture morphologies recognized primarily on the first and second phalanges and shaft fragments. The intensive exploitation of bones for marrow extraction, more attested in SU 31 than SU8, is confirmed by the fact that the epiphyseal portions represent the only identifiable part of long bones in the analysed sample. On the one hand, burnt bones are more frequent in SU8, localised in the inner part of the site where hunter-gatherers lived and carried out their daily activities, such as exploiting faunal resources. On the other hand, in SU31 burnt fragments are mixed up with unburnt remains and seem to be the result of waste discard. Some general inferences can be made in relation to the exploitation strategies for the available resources. Archaeozoological analysis has, in fact, revealed that red deer and ibex were the mostly hunted species, whereas to a lower extent but still significant, were chamois and roe deer. The few remains of wild boar and aurochs do not allow to formulate any plausible interpretation about their presence but they could be interpreted as food provisions transported from the valleys. The occupation of the site by carnivores appears to be occasional because of the few traces left and the few remains identified but bear could have been exploited by hunters.

Body part representation suggests that entire carcasses of red deer and ibex were introduced into the site and the absence of some skeletal parts among chamois and roe deer remains may either reflect a selective practice or could be the result of an intense fracturing of long bones that prevent their recognition. Finally, the presence of certain young individuals among ungulates (red deer and wild boar) confirms the occupation of the site in the late spring-summer season. It is therefore conceivable that during the seasonal migration of red deer at higher altitudes, groups of hunters followed the herds up to Mondeval where they settled, further exploiting even other species such as ibex.

The data related to faunal remains integrates well with the data obtained from the study of the lithic industry, which as far as SU 8 is concerned, sees the predominance of functional tools for hunting and processing of carcasses and animal hard materials (Fontana et al., 2009). It is also reasonable to suppose that some subsistence activities were conducted within the site, such as: slaughter, 
manufacturing of tools and flint knapping, within an area, that corresponds to SU 8. The same area was probably subjected to systematic cleaning action which resulted in the movement of larger fragments outside the site (SU 31).

Finally, results of these researches have demonstrated that despite its residential role, which is testified by the presence of dwelling structures and the high density of archaeological materials, this site shows a functional emphasis on activities attributable or related to animal carcass provisioning and processing. The latter belong mainly to red deer and ibex, the hunting of which was favoured by the optimal location of the site, in the transition zone between the alpine meadow and the upper limit of the forest. In virtue of this favorable position, groups of huntergatherers ascended to high altitudes during the spring and summer months so that they could exploit animals from different ecological niches.

\section{Acknowledgements}

SEM analysis was carried out with University of Ferrara - FAR 2012 grants. We would like to thank Dott.ssa Rita Bovolenta of the Centre of Electron Microscopy of the University of Ferrara, Dott. Marco Bertolini and Miss Sharada Channarayapatna.

\section{References}

Alciati, G., Cattani, L., Fontana, F., Gerhardinger, E., Guerreschi, A., Milliken, S. Mozzi, P., Rowley-Conwy, P., 1992. Mondeval de Sora: a high altitude Mesolithic camp-site in the Italian Dolomites. Preistoria Alpina 28 (1), 351-366.

Anconetani, P., Peretto, C., 1996. Fratturazione sperimentale su osso e osservazione sui reperti di scavo. Proposta di tipologia di fratturazione. In: Peretto, C. (Ed.), I Reperti Paleontologici del Giacimento Paleolitico di Isernia la Pineta. L'uomo e l'ambiente. Cosmo Iannone Editore, Isernia, pp. 531-549.

Angelucci, D.E., Alessio, M., Bartolomei, G., Cassoli, P.F., Improta, S., Maspero, A. Tagliacozzo, A., 1998. The Frea IV rockshelter (Selva val Gardena, BZ). Preistoria Alpina 34, 99-109.

Asmussen, B., 2008. Intentional or incidental thermal modification? Analysing site occupation via burned bone. Journal of Archaeological Science 36, 528-536.

Awsiuk, R., Bartolomei, G., Cattani, L., Cavallo, C., Dal meri, G., D'Errico, F. Giacobini, G., Girod, A., Hercman, H., Jardon-Giner, P., Nisbet, R., Pazdur, M.F., Peresani, M., Riedel, A., 1991. La grotta d'Ernesto (Trento): frequentazione umana e paleoambiente. Preistoria Alpina 27, 7-160.

Beherensmeyer, A.K., 1978. Taphonomic and ecologic information from bone weathering. Paleobiology 4, 150-162.

Behrensmeyer, A.K., Gordon, K.D., Yanagi, G.T., 1986. Trampling as a cause of bone surface damage and pseudo-cutmarks. Nature 319 (6065), 768-771.

Bennett, J.L., 1999. Thermal alteration of buried bone. Journal of Archaeological Science 26, 1-8.

Binford, L.R., 1981. Bones, Ancient Men and Modern Myths. Academic Press Inc., Orlando, Florida, p. 320.

Blasco, R., Rosell, J., Fernández Peris, J., Cáceres, I., Vergés, J.M., 2008. A new element of trampling: an experimental application on the level XII faunal record of Bolomor cave (Valencia, Spain). Journal of Archaeological Science 35, 1605-1618.

Blasco Sancho, M.F., 1992. Tafonomía y Prehistoria, métodos y procedimientos de investigación. Departamento de Ciencias de la Antiguedad (Prehistoria), Zaragoza.

Boscato, P., Sala, B., 1980. Dati paleontologici e cronologici di tre depositi epipaleolitici in Valle dell'Adige (TN). Preistoria Alpina 16, 45-61.

Brain, C.K., 1981. The Hunter or the Hunted? An Introduction to African Cave Taphonomy. University of Chicago Press, Chicago, p. 376.

Broglio, A., 1973. L'Epipaléolithique de la Vallée de l'Adige. L'Anthropologie 77 $(1-2), 5-34$.

Broglio, A., 1980. Culture ed ambienti della fine del Paleolitico e del Mesolitico nell'Italia nord-orientale. Preistoria Alpina 16, 7-29.

Broglio, A., 1992. Mountain sites in the context of North-East Italian upper Palaeolithic and Mesolithic. Preistoria Alpina 28 (1), 293-310.

Cilli, C., Malerba, G., Giacobini, G., 2000. Le modificazioni di superficie dei reperti in materia dura animale provenienti dai siti archeologici. Aspetti metodologici considerazioni tafonomiche. Bollettino del Museo Civico di Verona, sezione. Geologia, Paleontologia, Preistoria 24, 73-98.

Clark, R., 2000. The Mesolithic Hunters of the Trentino. A Case Study in Huntergatherer Settlement and Subsistence from Northern Italy, pp. 220. BAR International Series, 832.

Crezzini, J., Boschin, F., Boscato, P., Wierer, U., 2014. Wild cats and cut marks: exploitation of Felis silvestris in the Mesolithic of Galgenbüel/Dos de la Forca (South Tyrol, Italy). Quaternary International 330, 52-60.
Dalmeri, G. (Ed.), 2004. Studi sul Riparo la Cogola (Carbonare di Folgaria, Trento). Frequentazione umana e paleoambiente, pp. 89-200. Preistoria Alpina 40.

Domínguez-Rodrigo, M., De Juana, S., Galán, A., Rodríguez, M., 2009. A new protocol to differentiate trampling marks from butchery cut marks. Journal of Archaeological Science 36, 2643-2654.

Driesch, A. Von Den, 1976. A guide to the measurement of animal bones from archaeological sites. Peabody Museum Bulletins 1, 138.

Fiore, I., Tagliacozzo, A., 2004. Riparo Cogola: il contesto paleoecologico e lo sfruttamento delle risorse animali tra Epigravettiano e Mesolitico antico. Preistoria Alpina 40, 99-105.

Fontana, F., 2006. La sepoltura di Mondeval de Sora (Belluno). Differenziazione sociale e modalità insediative degli ultimi popoli cacciatori e raccoglitori dell'Italia nord-orientale. In: Martini, F. (Ed.), La cultura del morire nelle Società Preistoriche e Protostoriche italiane. Studio Interdisciplinare dei dati e loro Trattamento Informatico. Dal Paleolitico all'età del Rame. Istituto Italiano di Preistoria e Protostoria, pp. 269-292. Origines, Progetti 3.

Fontana, F., 2011. De saison en saison : réévaluation du statut fonctionnel des habitats sauveterriens du secteur nord oriental de la péninsule italienne et implications sur la mobilité des groupes humains. In: Haltes de chasse en préhistoire: Quelles réalités archéologiques ?, vol. 3, pp. 295-312. No. 1.

Fontana, F., Guerreschi, A., 2003. Highland occupation in the southern alps. In: Larsson, L. (Ed.), Mesolithic on the Move. Proceedings of the 6th International Conference on the Mesolithic in Europe, Stockholm. Oxbow Books, Oxford, pp. 96-102.

Fontana, F., Vullo, N., 2000. Organisation et fonction d'un camp de base saisonnier au coeur des Dolomites: le gisement mésolithique de Mondeval de Sora (Belluno, Italie). In: Richard, A., Cupillard, C., Richard, H., Thévenin, A. (Eds.), Les derniers chasseurs-cueilleurs d'Europe occidentale, Annales Littéraires, 699, 1. Environnement, Sociétés et Archéologie, pp. 97-208.

Fontana, F., Govoni, L., Guerreschi, A., Padoanello, S., Sala, B., Siviero, A., Thun Hohenstein, U., Ziggiotti, S., 2009a. L'occupazione sauveterriana di Mondeval de Sora 1, settore I (San Vito di Cadore, Belluno) in bilico tra accampamento residenziale e campo da caccia. Preistoria Alpina 44, 207-226.

Fontana, F., Guerreschi, A., Pasi, E., Petrucci, G., 2009b. Premiers résultats sur l'étude des niveaux sauveterriens du site 1, secteur III de Mondeval de Sora (Dolomites, Belluno, Italie). Rivista di Scienze Preistoriche LIX, 79-92.

Giacobini, G., 1995. Identificazione delle tracce di macellazione con strumenti litici. Analisi microscopica elettronica a scansione. In: Padusa Quaderni, 1, Atti del I Convegno Nazionale di Archeozoologia, pp. 29-31.

Giacobini, G., 1996. La ricerca tafonomica: una chiave per l'interpretazione dei siti preistorici. In: Oltre la pietra. Modelli e Tecnologie per Capire la Preistoria. Atti della Conferenza. ABACO Edizioni, Forlì, pp. 197-215.

Guerreschi, A., Fontana, F., Pizziolo, G., 2002. Analisi GIS dei livelli mesolitici del sito di Mondeval de Sora (San Vito di Cadore, Belluno). In: Peretto, C. (Ed.), Analisi Informatizzata e Trattamento dati delle Strutture di Abitato di età Preistorica e Protostorica in Italia. IIPP, Firenze, pp. 117-134.

Lyman, R.L., 1994. Vertebrate Taphonomy. Cambridge University Press, Cambridge.

Malerba, G. Giacobini, G. 1993. Osservazioni tafonomiche. In: Bartolomei, G. Broglio, A., Cassoli, P., Cremaschi, M., Giacobini, G., Malerba, G., Maspero, A., Peresani, M., Tagliacozzo, A. (Eds.), “Risultati Preliminari delle nuove Ricerche al Riparo di Fumane", Annuario Storico della Valpolicella, pp. 35-42, 1991-1992/ 1992-1993.

Myers, T.P., Voorhies, M.R., Conrner, R.G., 1980. Spiral fractures and bone pseudotools at paleontological sites. American Antiquity 45 (3), 483-490.

Olsen, S.L., Shipman, P., 1988. Surface modification on bone: trampling versus butchery. Journal of Archaeological Science 15, 535-553.

Outram, A.K., 2001. A new approach to identifying bone marrow and grease exploitation: why the indeterminate fragments should not be ignored. Journal of Archaeological Science 28, 401-410.

Peretto, C., Anconetani, P., Crovetto, C., Evangelista, L., Ferrari, M., Giusberti, G., Thun Hohenstein, U., Vianello, F., 1996. Approccio sperimentale alla comprensione delle attività di sussistenza condotte nel sito di Isernia La Pineta (Molise-Italia). La fratturazione intenzionale. In: Peretto, C. (Ed.), I Reperti Paleontologici del Giacimento Paleolitico di Isernia la Pineta, l'uomo e l'ambiente. Cosmo Iannone Editore, Isernia, pp. 187-451.

Peretto, C., Biagi, P., Boschian, G., Broglio, A., De Stefani, M., Fasani, L., Fontana, F., Grifoni, R., Guerreschi, A., Iacopini, A., Minelli, A., Pala, R., Peresani, M., Radi, G., Ronchitelli, A., Sarti, L., Thun Hohenstein, U., Tozzi, C., 2004. Living-floors and structures from the lower Palaeolithic to the Bronze age in Italy. Collegium antropologicum 28 (1), 63-88.

Rinaldi, G., 2010. L'occupazione Sauveterriana di Mondeval de Sora 1, Settore I (San Vito di Cadore, Belluno): Analisi Archeozoologica e Tafonomica dei Reperti Faunistici Provenienti dalle UUSS 14, 31, 32 e 33. University of Ferrara. MA. Unpublished thesis.

Sadek-Kooros, H., 1972. Primitive bone fracturing: a method of research. American Antiquity 37, 369-382.

Shipman, P., Foster, G., Schoeninger, M., 1984. Burn bones and teeth: an experimental study of color, morphology, crystal structure and shrinkage. Journal of Archaeological Science 11, 307-325.

Soldati, M., Dibona, D., Paganelli, A., Panizza, V., 1997. Evoluzione ambientale dell'area dell'Alpe Fedéra (Croda da Lago, Dolomiti). Studi Trentini di Scienze Naturali. Acta Geologica 71, 21-56.

Stiner, M.C., Kuhn, S.L., Weiner, S., Bar-Yosef, O., 1995. Differential burning, recrystallization, and fragmentation of archaeological bone. Journal of Archaeological Science 22, 223-227. 
Turrini, M.C., Fontana, F., Guerreschi, A., Thun Hohenstein, U., 2014. Distribution analysis of bone remains in the prehistoric site of Mondeval de Sora (Belluno Italy): issues and proposals. In: Earl, G., Sly, T., Chrysanthi, A., Murrieta-Flores, P., Papadopoulos, C., Romanowska, I., Wheatley, D. (Eds.), Archaeology in the Digital Era Volume II e-Papers from the 40th Conference on Computer Applications and Quantitative Methods in Archaeology Southampton, 26-30 March 2012, vol. II, pp. 480-486, 1.

Turrini, M.C., Rinaldi, G., Fontana, F., Guerreschi, A., Thun Hohenstein, U., 2015. Analisi spaziale della distribuzione dei ritrovamenti ossei combusti delle UUSS 8 e 31 nel sito preistorico di Mondeval de Sora (BL, Italia). In: Thun Hohenstein, U., Cangemi, M., Fiore, I., De Grossi Mazzorin, J. (Eds.), Atti del $7^{\circ}$ Convegno Nazionale di Archeozoologia. Annali dell'Università degli Studi di Ferrara: Museologia Scientifica e Naturalistica, 11, pp. 21-28, 2. http://dx.doi. org/10.15160/1824-2707/1056.
Villa, P., Mahieu, E., 1991. Breakage patterns of human long bones. Human Evolution 21, 27-48.

Vullo, N., Fontana, F., Guerreschi, A., 1999. The application of GIS to intra-site analysis: preliminary results from Alpe Veglia (VB) and Mondeval de Sora (BL), two Mesolithic sites in the Italian Alps. In: Barcelò, J.A., Briz, I., Vila, A. (Eds.), New Techiniques for Old Times, Proceedings of the $26^{\text {th }}$ Conference of Computer Applications and Quantitative Methods in Archaeology, pp. 111-115. BAR International Series 757.

Wierer, U., Boscato, P., 2006. Lo sfruttamento delle risorse animali nel sito mesolitico di Galgenbühel/Dos de la Forca, Salorno (Bz): la macrofauna. In: Tecchiati, U., Sala, B. (Eds.), Studi di Archeozoologia in onore di A. Riedel. Ufficio Beni Archeologici, Bolzano, pp. 85-98. 